furnish important evidence of racial relationships, migrations and mixtures. They were also useful in confirming conclusions regarding crossing reached on the grounds of physiognomy. In Section $A b$ (Anthropometry) a great part of the time available was devoted to the discussion of the system of measurement in anthropometry and its technique. Important progress was made. Further attention will be given to this subject later.

In Section $B$ (Psychology), a communication by Dr. C. S. Myers (London) was of special interest in its bearing on the current topic of mental characters and race. He pointed out th it while primitive man of to-day, it had been found, was not radically different from his more advanced brother, most of such differences as were observed were material for the social psychologist, for they were mainly due to the social factors of environment and tradition; nevertheless, the possible inheritance of "collective unconscious' factors could not be wholly ruled out.

In the same section, Prof. Arnold J. Toynbee (London), on "Psychological Problems which arise from the Contact of Cultures", said that the historians of the future would say that the great event of the twentieth century was the impact of Western civilisation upon all other living societies of the world of that day. The principle of national self-government had arisen in a West-European social environment, which was exceptional ; but the Near Eastern peoples had been led by West-European d minance to 'scrap' their own institutions, and havoc had ensued.

In the final session of the Congress, a number of important resolutions were passed and research committees appointed. It was decided that the next meeting of the Congress should take place in 1938 in Copenhagen, the president to be Prof. T. Thomsen of Copenhagen.

\title{
Lightning and High-Voltage Power Transmission Lines
}

$I^{N}$ a paper read to the South African Institute of Electrical Engineers in November last by E. F. Rendell and H. D. Gaff, an analysis is given of the faults due to lightning on the overhead lines connecting two stations-the Witbank and the Brakpan -belonging to the Victoria Falls and Transvaal Power Co. of South Africa. There are two parallel three-phase circuits connecting the two stations and the maximum load is 350 kilowatts. The voltage between phases is the same as that of the British Grid, namely, $132 \mathrm{kv}$. The three lines forming each set are of steel-cored aluminium and are in a vertical plane, the distance between the two planes being 23 feet. There is no transposition of the conductors (sometimes done to avoid interference with neighbouring telephones) and so they are parallel to one another. The distance between the top conductor of a set and the middle conductor is $12 \mathrm{ft}$., being the same as the distance between the middle and the lower conductor. An earthed guard wire was originally placed above the two sets at a distance of $18 \mathrm{ft}$. from the top wire of each set. The height of the lowest conductors from the earth averages $56 \mathrm{ft}$. The function of the guard wire is to 'protect' the circuits from lightning. There are 303 suspension towers for the circuits between the two stations.

Two cinematograph cameras were installed at Witbank, and one at Brakpan, three years ago. Any full voltage fault automatically starts the cameras recording. In this way, very complete film records have been obtained of the currents, voltages, etc., during every fault for the last three years. It is generally agreed that there are four possible ways in which a lightning fault may be caused on a power line. It may be due to the induced voltage in the conductors causing a rise of pressure which flashes over the string of insulators to the earth. Or it may bs due to the lightning flash striking a suspension towər directly. It might strike a conductor directly. There is a possibility also that a streamer from a lightning flash to the earth might strike a conductor. The records provide some evidence that the first two causes are quite possible, but they only give negative results with regard to the last two.

It is well known that lightning faults are rarely evenly distributed along the length of a transmission line. In general, some sections of the line are immune from faults whilst in other sections, severe and continually recurring faults may be experienced. The reasons usually given are varying radioactivity on the geological strata causing more frequent flashes in certain locations. Variations in the electrical resistivity of the geological strata, which have the effect of altering the resistance to the earth of the various towers, may have an effect on the frequency of the occurrence of the faults. The records show that no faults occurred between towers 264-297, a distance of about six miles, and there were 65 between towers $120-164$, a distance of roughly eight miles. Owing to faults recurring in a particular section, additional guard wires were erected over it. This, however, seems to have had the effect of increasing the number of faults.

The authors have found that there are appreciable differences in what happens when a fault on a single line occurs and when there is a simultaneous fault on two lines. The differences occurred so consistently that they indicate a fundamental difference in the active cause in the two cases. When a fault occurs on one of the circuits only, it is rare for more than one phase to be affected. With double-line faults, the majority occur on only one phase, but there are an appreciable number affecting two phases. Invariably the same phase or phases of both lines are affected. With single-line faults, the top conductor is the one most frequently affected; with double-line faults all phases are approximately equally affected. The equal distribution of faults between all phases in the case of double-line faults suggests that such a fault is due to a direct stroke on the tower causing an over-voltage, and consequently the highest conductors at the instant of the stroke are the ones affected.

The value of the resistance to earth of a tower seems to have little effect on the number of singleline faults that occur. With double-line faults, on the other hand, increasing the insulation diminishes their number without increasing the number of faults on neighbouring towers. The records show quite definitely that with single-line faults the conductor furthest removed from the earth is the one most frequently struck, whilst with double-line faults the conductors are all equally liable to be struck. They also show that with single-line faults additional 
guard wires decrease the number of faults and protect the top conductor but apparently make the bottom conductor more liable to be struck. On the other hand, simultaneous double-line faults seem to occur more frequently when guard wires are used.

In spite of the severity of the storms that occur in the Rand, the operation of a single line of towers carrying two power lines has been successful. Since they started operation in April 1926 they have never been rendered unserviceable by a lightning fault. Most engineers would prefer to have two separate rows of towers several hundred metres apart each carrying three wires which form the edges of an equilateral prism. Some of the phenomena that would occur in this case would doubtless be similar to those observed by the authors.

\section{Atmospheric Pollution}

$\mathrm{T}$ HERE is an impression that American cities are smoke free. This is only true to a limited extent, and in some respects Americans are very tolerant. The smoke of an American railway engine must be seen to be believed, and Dr. Meller's broadcast talk on December 28, 1933 ("The Smoke Abatement Outlook". By H. B. Meller. The Mellon Institute, Pittsburgh), tells a tale of the evil and damage done by smoke, which reads very familiar. He makes the point that following water, sanitation and food comes naturally the need to improve the quality of our air supply. "Remember," he says, "the demand we are now hearing for a new deal in air is coming from those who are living in houses of the type to which we long have been accustomed. How much stronger will be the cry for effective abatement of smoke when we begin to promote construction of the new style dwellinghouse which seience has developed. Samples of such houses were enthusiastically viewed for the first time by the masses at the Century of Progress Exposition. Small houses they are, with flat roof surfaces devoted to play spaces and sun parlours ; all of them equipped for air conditioning ; every one constructed so that each room can be flooded with sunlight. In short, dwellings designed to make much fuller use of free and inexhaustible health-giving natural resourcespure air and unfiltered sunlight. Smoke challenges the use and enjoyment of houses of the new type. Excessive air pollution largely defeats the purposes of a roof playground and sun parlor. The sooner we realise these facts, the quicker we will take steps to bring smoke under adequate control."

Dr. Meller goes on to plead for withdrawing exemption from smoke abatement ordinances from domestic fires and due attention to atmospheric pollution in schemes of rehousing. Both pleas are also relevant in Great Britain. The traditional pitched roof was inevitable so long as available weatherproof materials could only be got in small pieces, but quite unnecessary now that modern methods and materials of construction enable the flat roof to be easily made. Flat roofs would greatly increase the effective area of cities, as a glance at maps will show, and that without extending the boundaries. Moreover, this roof area, the most remote from traffic and noise, will be increasingly prized as smoke is diminished. The realisation of all this may be expected to increase the call for cleaner atmosphere by many who are now indifferent--householders, property owners and civic authorities. Unfortunately it is just here where individual action is so ineffective, and full benefit can only be realised by the construction of whole estates without smoky appliances. What an opportunity is presented by our new housing schemes if only it could be grasped !

The report of the investigation on air pollution described by the Department of Scientific and Industrial Research (H.M. Stationery Office. 5s. net) shows that systematic recording is increasing and that improvement of atmospheric conditions continues. Pollution by motor exhausts has been examined this year, but systematic recording is not deemed necessary. The deposit of tar, compared with the average of the previous five years, was lower by 14 per cent and of total solids by 11 per cent. Deposition of sulphates has also diminished. The highest figure was recorded at Ravenscourt Park, London, and the lowest at Templenewsam Park in East Leeds. Westminster is one of the worst spots in the country for smoke haze, from which again Coventry is practically free. Coventry is a model city in this respect, whereas London compares unfavourably with many industrial towns.

The limited measurements available indicate that the loss of sunlight due to air pollution averages 20 per cent over the year and more than this in winter. Last year the reasons for the fine records for Coventry were given as being partly geographical and partly the extensive use of smokeless methods in domestic and industrial practice. The lesson of these records cannot be too widely published at the present time,

H. J. H.

\section{University and Educational Intelligence}

CAMBridge.-The General Board has given notice that Dr. C. G. Lamb will resign the readership in electrical engineering on September 30, but it is not intended to recommend the continuation of the readership.

R. D. Davies, of Gonville and Caius College, has been appointed University demonstrator in engineering.

At King's College, A. M. Turing has been elected to a Harold Fry studentship, K. C. Dixon to an additional Harold Fry studentship and J. W. S. Pringle to a Martin Thackeray studentship.

At Trinity College, Dr. L. Borinski has been elected to a research studentship and W. E. Bennett and D. P. R. Petrie have been elected to Dominion and Colonial exhibitions in physics.

A crNema museum, wherein should be housed films of outstanding artistic and scientific merit, is advocated in an article by Elma Dangerfield in a recent issue of Film Progress. The project is linked with the scheme of the Shakespeare Film Society formed under the chairmanship of Sir Frank Benson. The same issue of Film Progress contains a very informa. tive article by Charles Brawn, which relates how during the past five years he has evolved a successful technique of exhibition of films in schools, and formulates a number of definite conclusions arrived at by the school staff as a result of five years' experience. It seems clear that films are playing an increasingly important part in schools. A glance at a recent issue of a school magazine (Stoic, April) shows that the cinema figures prominently in seven separate reports of extra-curricular activities, including those of a natural science society, a natural history society, a film society and a motion picture 